\title{
PENGARUH MODEL PEMBELAJARAN INKUIRI TERHADAP KEMAMPUAN PENALARAN MATEMATIS SISWA KELAS XI SMA NEGERI 1 GEBANG TAHUN AJARAN 2018/2019
}

\author{
Sri Wahyuni ${ }^{1}$, Joshua Pandapotan Silalahi ${ }^{2}$, Juwita Erdaini ${ }^{3}$ \\ STKIP Budidaya Binjai \\ Email: ${ }^{1}$ yuni210984gmail.com, ${ }^{2}$ joshuapandapotan@gmail.com
}

\begin{abstract}
ABSTRAK
Tujuan penelitian ini untuk menganalisis pengaruh model pembelajaran Inkuiri terhadap kemampuan penalaran matematis siswa. Penelitian ini dilakukan di SMA Negeri 1 Gebang Tahun Ajaran 2018/2019. Jenis Penelitian adalah penelitian quasi eksperimen (Eksperimen Semu) dengan desain penelitian One group pretest-posttes design. Sampel yang digunakan dalam penelitian ini adalah kelas XI MIA-2 sebagai kelas eksperimen. Subjek penelitian ini adalah 32 siswa kelas eksperimen. Instrument yang digunakan dalam penelitian ini berupa tes kemampuan penalaran matematis siswa berbentuk uraian sebanyak 4 soal. Uji prasyarat yang digunakan adalah uji Liliefors untuk menguji normalitas data. Berdasarkan hasil uji normalitas diperoleh bahwa sampel yang digunakan penulis berditribusi normal.Berdasarkan hasil penelitian mengungkapkan bahwa model pembelajaran Inkuiri sangat berpengaruh terhadap kemampuan penalaran matematis siswa. Hal ini dapat dilihat dari nilai rata-rata posttests hasil tes kemampuan penalaran matematis siswa yang telah diajarkan dengan model pembelajaran Inkuiri adalah lebih tinggi dari pada nilai rata-rata preteset, sehingga didapatkan bahwa model pembelajaran Inkuiri memiliki pengaruh. Kesimpulan hasil penelitian ini adalah bahwa pembelajaran matematika dengan menggunakan model pembelajaran Inkuiri berpengaruh terhadap kemampuan penalaran matematis siswa.
\end{abstract}

Kata kunci: Model Inkuiri, Kemampuan Penalaran matematis

\section{PENDAHULUAN}

Kemampuan penalaran dan pemecahan masalah matematis memiliki peranan yang sangat penting dalam tercapainya tujuan pendidikan matematika di sekolah. Selain itu, kemampuan penalaran dan pemecahan masalah juga diperlukan untuk keberhasilan siswa di sekolah.

Berdasarkan beberapa hasil penelitian yang diperoleh, alasan mengapa prestasi matematika rendah adalah rendahnya penalaran dan pemecahan masalah siswa. Hal ini terbukti melalui pelaksanaan UNBK SMA sederajat tahun 2018 yang berlangsung pada bulan April lalu, yakni pada soal-soal yang diujikan lebih banyak yang menggunakan atau menggabungkan unsur High Order Thinking Skill (HOTS) atau sering disebut dengan daya nalar tingkat tinggi pada mata pelajaran yang diujiankan khususnya Matematika baik itu pada jurusan MIA maupun IPS. Abduh (dalam Waspada) menuturkan bahwa mulai tahun 2018 ini, Kemendikbud akan memberlakukan soal yang membutuhkan daya nalar tingkat tinggi pada UN tahun 2018. Hal ini bertujuan untuk meningkatkan kualitas dari UN tersebut 
dengan memasukkan soal HOTS tersebut. ${ }^{1}$ Secara tidak langsung, beliau menginginkan tingkat penalaran siswa SMA harus mengalami peningkatan dari tahun-tahun sebelumnya. Namun, bukan berarti soal UN pada tahun sebelumnya tidak berbobot, tetapi beliau menginginkan ada peningkatan yang berbeda dari tahun sebelumnya.

Hal tersebut pun penulis temukan di SMA Negeri 1 Gebang sebagai objek penelitian dalam karya tulis ini. Setelah penulis melakukan tes pendahuluan ternyata penalaran matematis siswa di SMA Negeri 1 Gebang masih rendah . Berdasarkan hasil wawancara penulis dengan salah seorang pendidik pendidikan matematika bernama Hilda Agustiawati, S.Pd, kemampuan penalaran siswa mengalami penurunan dari tahun sebelumnya, karena di setiap kelas hanya sekitar 3-5 siswa saja yang mampu mengiuti pembelajaran dan itu adalah siswa yang mengambil jurusan MIA saja. Pernyataan ini pun diperkuat oleh PKS bidang kurikulum yang bernama Dra. Berlian Silaban, M.Pd, yang menyatakan bahwa kemampuan penalaran matematis siswa sangat menurun dari pertama kali beliau ditempatkan di SMA Negeri 1 Gebang pada tahun 1993. Bahkan, setelah diberikan beberapa soal yang berbasis penalaran kepada siswa ternyata memang hanya beberapa siswa saja yang mampu menjawab.

Kemudian, dalam menyikapi masalah tersebut seharusnya pendidik matematika bertanggung jawab dalam memberikan solusi. Pendidik hendaknya dapat membuat siswa tertarik dan mengubah pola belajar yang cenderung pasif (hanya menerima) menjadi lebih aktif dalam belajar sehingga siswa dapat menggunakan penalarannya. Salah satu model pembelajaran yang diusulkan oleh penulis sebagai solusi adalah dengan menggunakan model pembelaran Inkuiri. Alasan penulis memilih/mengusulkan model pembelajaran Inkuiri ini diperkuat dengan keberhasilan dari para penulis sebelumnya, seperti: Parjayanti. A.D, dan Wardono, serta Widiastuti dan Rusgianto Heri Santosa. Mereka adalah para penulis yang sebelumnya juga mengusulkan model pembelajaran Inkuiri sebagai solusi untuk meningkatkan daya nalar pemahaman matematis siswa. Oleh sebab itu, penulis semakin tertarik untuk membahas tentang model pembelajaran Inkuiri dalam karya tulis ini.

Inkuiri berasal dari kata to inquire yang berarti ikut serta atau terlibat dalam mengajukan pertanyaan-pertanyaan, mencari informasi, dan melakukan penyelidikan (Yuniyanti dalam Parjayanti, A.D. dan Wardono). ${ }^{2}$ Menurut Sund dan Trowbridge sebagaimana dikutip oleh Opara (dalam Parjayanti, A.D. dan Wardono), mendefinisikan Inkuiri sebagai model pengajaran bertujuan untuk mengetahui bagaimana para ilmuwan mengembangkan, memahami dan menerapkan pengetahuan baru melalui pertanyaan sistematis, hipotesa dan bereksperimen yang melibatkan penemuan darMIAda verifikasi fakta yaitu "mencari darMIAda hasil". ${ }^{3}$ Jadi, model pembelajaran Inkuiri merupakan suatu

\footnotetext{
${ }^{1}$ Waspada, Pengamat Kritik Soal HOTS di UNBK 2018, Senin 14 April 2018, hlm. 1

${ }^{2}$ Parjayanti, A.D. dan Wardono, Studi Komparasi Model Pembelajaran Antara Inkuiri Dan Advance Organizer Untuk Penalaran Matematis, Jurnal Kreano, ISSN : 2086-2334, Vol. 4, No. 1, hlm. 65

${ }^{3}$ Ibid., hlm. 65
} 
model pembelajaran yang dikembangkan berdasarkan cara berpikir yang bersifat penemuan yaitu menarik kesimpulan berdasarkan data-data yang teramati.

Pemilihan model pembelajaran Inkuiri tepat digunakan untuk meningkatkan kemampuan penalaran matematis siswa karena model pembelajaran Inkuiri mendorong siswa untuk memiliki keingintahuan dan ingin berkembang. Model pembelajaran Inkuiri ini bertujuan untuk memberikan cara bagi siswa untuk membangun kecakapan-kecakapan intelektual (kecakapan berpikir) terkait dengan proses-proses berpikir reflektif (Yuniyanti dalam Parjayanti, A.D. dan Wardono). ${ }^{4}$ Proses Inkuiri atau penyelidikan dalam penelitian ini dilakukan di bawah bimbingan pendidik dan bimbingan tersebut dituangkan dalam Lembar Aktifitas Siswa (LAS).

Berdasarkan latar belakang di atas, maka dapat dirumuskan permasalahan sebagai berikut: "Apakah ada pengaruh model pembelajaran Inkuiri terhadap kemampuan penalaran matematis siswa kelas XI di SMA Negeri 1 Gebang, berdasarkan rumusan masalah yang telah dikemukakan, penelitian ini bertujuan untuk mengetahui pengaruh model pembelajaran Inkuiri terhadap kemampuan penalaran matematis siswa kelas XI di SMA Negeri 1 Gebang.

Rumusan hipotesis penelitian yang diajukan dalam penelitian ini adalah terdapat pengaruh model pembelajaran Inkuiri terhadap kemampuan penalaran matematis siswa Kelas XI SMA Negeri 1 Gebang Tahun Ajaran 2018/2019.

\section{METODE}

Jenis Metode dalam penelitian ini adalah ekperimen dalam bentuk preexperimental designs (non designs). Desain penelitian yang digunakan dalam penelitian eksperimen ini adalah One Group Pretest-Posttest Design, adapun gambaran mengenai rancangan One Group Pretest-Posttest Design menurut Sugiyono (2009 : 112) sebagai berikut:

$$
\mathrm{O}_{1} \quad \mathrm{X} \quad \mathrm{O}_{2}
$$

Keterangan :

$\mathrm{O}_{1} \quad$ : Nilai pretest (sebelum diberi diklat)

$\mathrm{O}_{2} \quad$ : Nilai posttest (sesudah diberi diklat

Penelitian ini akan dilaksanakan di sekolah SMA Negeri 1 Gebang. Pelaksaan penelitian akan dilaksanakan pada semester ganjil tahun ajaran 2018/2019 pada bulan Agustus sampai September sebanyak lima kali pertemuan.

Populasi dalam penelitian ini adalah seluruh siswa kelas XI SMA Negeri 1 Gebang Tahun Pelajaran 2018/2019 yang terdiri dari atas kelas yang terdiri atas 7 kelas yaitu XI MIA-1, XI MIA2, XI MIA-3, XI MIA-4, IPS-1, IPS-2, dan IPS-3, banyak siswa seluruhnya adalah 232 siswa. Dalam penentuan pemilihan sampel ini, teknik sampling yang digunakan adalah Puposive sampling atau judgmental sampling. Dalam teknik sampling ini, penarikan sample dilakukan dengan

${ }^{4}$ Ibid., hlm. 65 
memilih subjek berdasarkan kriteria spesifik yang dietapkan penulis. ${ }^{5}$ Adapun sampel yang digunakan dalam penelitian ini adalah satu kelas yaitu kelas XI MIA 2, dimana kelas XI MIA 2 sekaligus bisa dikatakan sebagai kelas eksperimen jumlahnya 32 siswa.

Teknik pengumpulan data menggunakan tes. Teknik tes digunakan untuk mengukur ketercapaian kompetensi dasar dan kemampuan penalaran matematis siswa.

Analisis data dilakukan setelah data dari sampel melalui instrumen terkumpul. Teknik analisa data yang digunakan adalah uji statistik. Melalui uji statistik ini, dapat digunakan untuk menghitung data-data yang diperoleh dan nantinya dapat dianalisis.

1. Uji Normalitas

Uji normalitas digunakan untuk mengetahui data yang akan dianalisis tersebut berdistribusi normal atau tidak. Suatu data yang berdistribusi normal. Bila jumlah data di atas dan di bawah rata-rata adalah sama, demikian juga simpangan bakunya.

Hipotesis :

$\mathrm{H}_{0} \quad$ : data berdistribusi normal

$\mathrm{H}_{1} \quad$ : data tidakberdistribusi normal

Adapun rumus yang digunakan dalam uji normalitas ini adalah uji Lilliefors.

1. Uji Regresi

$\hat{Y}=a+b x \quad$ (Sumber: Sudjana) ${ }^{6}$

Keterangan :

$\mathrm{Y}=$ Subjek dalam variable terkait yang diprediksikan

$\mathrm{a}=$ Angka arah atau koefisien regresi, yang menunjukkan angka peningkatan ataupun penurunan variabel terikat yang didasarkan pada perubahan variabel bebas

$\mathrm{b}=$ Harga $\mathrm{Y}$ ketika harga $\mathrm{X}=0$ (harga konstan)

$\mathrm{X}=$ Subjek pada variabel bebas yang mempunyai nilai tertentu.

Sebelum analisis regresi digunakan maka diperlukan uji keberartian dan uji linieritas terlebih dahulu.

a. Uji Keberartian

Hipotesis statistik:

$\mathrm{H}_{0}: \mathrm{b}=0$

$\mathrm{H}_{\mathrm{a}}: \mathrm{b} \neq 0$

Hipotesis Kalimat:

$\mathrm{H}_{0}=$ koefisien arah regresi yang tidak berarti

$\mathrm{H}_{\mathrm{a}}=$ koefisien arah regresi yang berarti

Untuk menguji $\mathrm{H}_{0}$ digunakan rumus statistik $\mathrm{F}=\frac{\mathrm{S}^{2} \text { reg }}{\mathrm{S}^{2} \text { res }}$.

b. Uji Linieritas

Hipotesis Statistik:

$\mathrm{H}_{0}: \hat{Y}=a x+b$

${ }^{5}$ Drs. Kuntjojo, M.Pd., Metodologi Penelitian, (Kediri, 2009). hlm.32.

${ }^{6}$ Ibid., hlm. 341 
$\mathrm{H}_{\mathrm{a}}: \hat{Y} \neq a x+b$

Hipotesis Kalimat :

$\mathrm{H}_{0}=$ Regresi linier

$\mathrm{H}_{\mathrm{a}}=$ Regresi non linier

Untuk menguji $\mathrm{H}_{0}$ digunakan rumus statistik $\mathrm{F}=\frac{\mathrm{S}^{2} \mathrm{TC}}{\mathrm{S}^{2} \mathrm{E}}$.

Untuk mempermudah melakukan uji keberartian dan uji linieritas berikut disajikan daftar analisis varians (ANAVA) regresi linier sederhana

Tabel 1. Rekapitulasi Hasil Perhitungan Uji Normalitas Pretest dengan Uji

liliefors

\begin{tabular}{|c|c|c|c|c|}
\hline Data & $\mathbf{L}_{\mathbf{0}}$ & $\mathbf{L}_{\mathbf{t}}$ & Kes. & Ket \\
\hline Pretest & 0,15565 & 0,1566 & $\begin{array}{c}\text { Terima } \\
\mathrm{H}_{0}\end{array}$ & Normal \\
\hline
\end{tabular}

Pada tabel 4.3 dapat disimpulkan bahwa kelas eksperimen diperoleh $(0,15565<$ $0,1566)$ dapat disimpulkan bahwa data berasal dari sampel yang berdistribusi normal

Tabel 2. Rekapitulasi Hasil Perhitungan Uji Normalitas Posttest dengan Uji

liliefors

\begin{tabular}{|c|c|c|c|c|}
\hline Data & $\mathbf{L}_{\mathbf{0}}$ & $\mathbf{L}_{\mathbf{t}}$ & Kes. & Ket \\
\hline Posttest & 0,1489 & 0,1566 & Terima $\mathrm{H}_{0}$ & Normal \\
\hline
\end{tabular}

Pada tabel 4.4 dapat disimpulkan bahwa kelas eksperimen diperoleh $(0,1489<$ $0,1566)$ dapat disimpulkan bahwa data berasal dari sampel yang berdistribusi normal.

\section{Pengujian Hipotesis}

1) Analisis Regresi

a) Regresi Pada Kelas Eksperimen

Model regresi linier antara variabel terikat Y (Data posttest) dengan variabel bebas $\mathrm{X}$ (Data Pretest) dinyatakan dalam $\mathrm{Y}=\mathrm{a}+\mathrm{bX}$. Sehingga persamaan garis regresi: $\mathrm{Y}=46,70+2,60 \mathrm{X}$

b) Uji Keberartian Koefisien Regresi pada Kelas Eksperimen

Tabel Hasil Perhitungan Keberartian Koefisien Regresi Pada Kelas Eksperimen

\begin{tabular}{|c|c|c|c|c|c|}
\hline Varians & JK & Db & RJK & Fhitung & Ftabel \\
\hline Total & 127072 & 32 & & \multirow{3}{*}{28,811} & \multirow{3}{*}{4,17088} \\
\hline $\begin{array}{l}\text { Regresi } \\
\text { (a) }\end{array}$ & 120786,125 & 1 & 120786,125 & & \\
\hline $\begin{array}{c}\text { Regresi } \\
\text { (b/a) }\end{array}$ & 550,7917 & 1 & 550,7917 & & \\
\hline
\end{tabular}

Berdasarkan tabel hasil perhitungan keberartian koefisien regresi diperoleh $F_{\text {tabel }}=4,170877$. Dengan demikian dapat dilihat bahwa $F_{\text {hitung }}>F_{\text {tabel }}$ yaitu 28,811 $>4,17088$ maka $\mathrm{H}_{0}$ ditolak. Jika harga $\mathrm{F}_{\text {hitung }}>\mathrm{F}_{\text {tabel }}$ maka harga $\mathrm{F}_{\text {hitung }}$ yang diperoleh signifikan. Hal ini menunjukkan bahwa koefisien arah regresi untuk kelas eksperimen berarti dengan taraf signifikan $5 \%$.

Uji Hipotesis Model Pembelajaran Inkuiri

Tabel Data Kemampuan Penalaran Siswa

\begin{tabular}{|c|c|c|c|c|}
\hline \multirow{2}{*}{ Kategori } & \multicolumn{2}{|c|}{ Pretest } & \multicolumn{2}{c|}{ Posttest } \\
\cline { 2 - 5 } & \multicolumn{2}{|c|}{ Eksperimen } & \multicolumn{2}{c|}{ Eksperimen } \\
\hline Rendah & 4 & $12,5 \%$ & - & $0 \%$ \\
\hline Cukup & 16 & $50 \%$ & 16 & $50 \%$ \\
\hline Tinggi & 8 & $25 \%$ & 13 & $40.6 \%$ \\
\hline Sangat Tinggi & 4 & $12,5 \%$ & 3 & $9,38 \%$ \\
\hline
\end{tabular}

Tabel Hasil Uji Hipotesis 


\begin{tabular}{|c|c|c|c|c|}
\hline Hubungan & $\mathbf{R}$ & $\mathbf{r}^{2}$ & $\mathbf{D}=\mathbf{r}^{2} \mathbf{x 1 0 0 \%}$ & $\begin{array}{c}\text { Garis } \\
\text { regresi }\end{array}$ \\
\hline $\begin{array}{c}\text { Model } \\
\text { pembelajaran } \\
\text { Inkuiri }\end{array}$ & 0,6 & 0,37 & $37,21 \%$ & $\mathrm{Y}=46,70+$ \\
21 & $2,60 \mathrm{X}$ \\
\hline
\end{tabular}

Dari hasil perhitungan diperoleh $r=0,61$ karena $r \neq 0$. Maka dapat disimpulkan bahwa pada taraf sinifikan 5\% $(0,05)$ Terdapat pengaruh model pembelajaran model pembelajaran Inkuiri terhadap kemampuan penalaran matematis siswa. Dimana besarnya pengaruh model pembelajaran Inkuiri terhadap kemampuan penalaran matematis siswa sebesar $37,21 \%$. Dengan demikian dapat dikatakan bahwa model pembelajaran Inkuiri berpengaruh sangat besar terhadap kemampuan penalaran matematis siswa.

\section{HASIL DAN PEMBAHASAN}

Berdasarkan uji regresi linear sederhana diperoleh $r_{\text {tabel }}=1,43$, sementara berdasarkan perhitungan yang telah dilakukan diperoleh $r_{\text {hitung }}=2,60$. Dari perhitungan terlihat bahwa $r_{\text {hitung }}>r_{\text {tabel }}(2,60>1,43)$ maka hipotesis yang diajukkan diterima. Dengan demikian, maka hasilnya dapat dikemukakan bahwa: "adanya pengaruh model pembelajaran Inkuiri terhadap kemampuan penalaran matematis siswa kelas XI SMA Negeri 1 Gebang tahun pelajaran 2018/2019”.

Model pembelajaran Inkuiri berpengaruh terhadap kemampuan penalaran matematis siswa, sebab dalam pembelajaran ini siswa bekerja sama dalam kelompok untuk menemukan masalah pada soal LAS yang diberikan oleh guru sehingga siswa dan guru saling melakukan interaksi berupa tanya jawab apa yang kurang dipahami oleh siswa. Pelaksanaan pembelajaran pada kelas eksperimen dan kelas kontrol masing masing membutuhkan 4 kali pertemuan.

Berdasarkan uraian di atas, dapat dikatakan bahwa "Terdapat pengaruh model pembelajaran Inkuiri terhadap kemampuan penalaran matematis pada pokok bahasan suku banyak kelas XI SMA Negeri 1 Gebang tahun pelajaran 2018/2019”.

\section{SIMPULAN}

Berdasarkan analisis data dan pembahasan maka dapat disimpulkan bahwa Model pembelajaran Inkuiridapat memberikan pengaruh atas hasil kemampuan penalaran matematika pokok bahasan suku banyak kelas XI SMA Negeri 1 Gebang Tahun Pelajaran 2018/2019

\section{REFERENSI}

Arikunto, Suharsimi. Prosedur Penelitian Suatu Pendekatan Praktik. Jakarta:Rineka Cipta. 2013

D, Parjayanti A. dan Wardono. Studi Komparasi Model Pembelajaran Antara Inkuiri Dan Advance Organizer Untuk Penalaran Matematis. Jurnal

Kreano. ISSN : 2086-2334. Vol. 4. No. 1. hlm. 65. 2013 
Kuntjojo. Metodologi Penelitian. Kediri. 2009

Sugiyono. Metode Penelitian Pendidikan. Bandung : Alfabeta. 2012

Waspada. Pengamat Kritik Soal HOTS di UNBK 2018. Senin 14 April 2018 